\title{
Entrepreneurial intention in developed and developing countries: a comparative between G7 and BRICS countries
}

\author{
Intenção empreendedora em países desenvolvidos e em desenvolvimento: uma \\ comparação entre países do G7 e BRICS
}

Carla Carolinne dos Santos Silva ${ }^{1}$

Orcid: https://orcid.org/0000-0002-2528-2628

\author{
André Luiz Cavalcanti ${ }^{2}$ \\ Orcid: https://orcid.org/0000-0003-0011-6532
}

\author{
Ricardo Gouveia Rodrigues ${ }^{3}$ \\ Orcid: https://orcid.org/0000-0001-6382-5147
}

\begin{abstract}
The objective of this study is to investigate a possible difference in entrepreneurial intention between developed and developing countries. For this purpose, we used the data of the year 2014 of the Adult Population Survey, made available by the Global Entrepreneurship Monitor (GEM). The intentional sample was defined based on two groups: developed countries belonging to the G7 and developing countries, belonging to BRICS. To test the hypotheses, we used non-parametric tests for categorical data. The results show that BRICS countries have greater entrepreneurial intention when compared to the G7 countries. In addition, the BRICS countries do not have the same perception and entrepreneurial intention; finally, we found that men have a greater entrepreneurial intention when compared to women. The study contributes to the literature of entrepreneurship, more particularly when it comes to entrepreneurial profile and intention, advancing with comparative studies between countries with different economic, cultural and social characteristics.
\end{abstract}

Keywords: Entrepreneurial intention. Developed countries. Developing countries. G7. BRICS.

\begin{abstract}
Resumo
O objetivo deste estudo é investigar uma possível diferença na intenção empreendedora entre países desenvolvidos e em desenvolvimento. Para isso, foram utilizados os dados do ano de 2014 da Pesquisa de População Adulto, disponibilizada pelo Global Entrepreneurship Monitor (GEM). A amostra intencional foi definida com base em dois grupos: países desenvolvidos pertencentes ao G7 e países em desenvolvimento pertencentes ao BRICS. Para testar as hipóteses, foram utilizados testes não paramétricos para dados categóricos. Os resultados mostram que os países do BRICS têm maior intenção empreendedora quando comparados aos países do G7. Além disso, os países do BRICS não têm a mesma percepção e intenção empreendedora; finalmente, descobrimos que os homens têm uma maior intenção empreendedora quando comparados às mulheres. $\mathrm{O}$ estudo contribui para a literatura sobre empreendedorismo, mais particularmente no que se refere ao perfil e intenção empreendedores, avançando com estudos comparativos entre países com diferentes características econômicas, culturais e sociais.
\end{abstract}

Palavras-chave: Intenção empreendedora. Países desenvolvidos. Países em desenvolvimento. G7. BRICS.

\footnotetext{
${ }^{1}$ Universidade da Beira Interior - UBI, Portugal. E-mail: carlacarolinnes@gmail.com

${ }^{2}$ Universidade da Beira Interior - UBI, Portugal. E-mail: cavalcanti_17@hotmail.com

${ }^{3}$ Universidade da Beira Interior - UBI, Portugal. E-mail: rgrodrigues@ubi.pt
} 


\section{INTRODUCTION}

The entrepreneurial capacity of a country is directly aligned with the increase of the competitiveness and the economy of the same, demonstrating representativeness and relevance. However, several factors can influence this capacity, such as the culture of a country, laws and bureaucracies, politics, among many other possible. When observing developed and developing countries, a difference between the scenarios to be undertaken is evident, that is, the starting point for entrepreneurship has several peculiarities (WAHEEDUZZAMAN, 2011; GHANEM, 2013; MOSTAFA; MAHMOOD, 2015).

For years, the G7 countries (the group formed by Britain, France, Germany, USA, Japan, Italy and Canada) were considered as the main economies of the world, which could then provide scenarios of higher levels of enterprise, (Brazil, Russia, India, China, and Africa), began to stand out as growing economies with high levels of entrepreneurial intention (NADEEM et al., 2017). However, little has been studied about the differences in the entrepreneurial profile in these two groups of countries, besides understanding what characteristics the developing countries have in order to achieve such growth and relevance for the world economy (BRUTON et al., 2008; IAKOVLEVA, 2007; MORAES et al., 2018). Thus, the present study aims to: investigate a possible difference in entrepreneurial intention between developed and developing countries. In addition, it proposes to analyze the differences in the entrepreneurial profile among the BRICS countries. To answer this objective, we used the secondary data extracted from the database provided by the Global Entrepreneurship Monitor (GEM).

The literature presents several definitions of Individual Entrepreneurship (EI) (Hayton, Cacciotti, 2014; Law, Breznik, 2017), however, it is observed that there is a common point between them, which is the fact that they approach IE as the individual's attitude in undertaking. This theme has been highlighted in studies on entrepreneurship because it is an analysis of individuals, allowing to address, for example, their background (Law, Breznik, 2017), the factors of the context where these individuals are inserted (Hayton, Cacciotti, 2014 ), the influence of culture (Reardon, 1991) and other diverse possibilities, since it is a comprehensive theme, which allows it to be explored in different contexts.

The present study contributes to the entrepreneurship literature, more particularly when it comes to the profile and entrepreneurial intention, advancing with comparative studies among countries with different economic, cultural and social characteristics. The results of this study also contribute to identifying that developing countries have a greater entrepreneurial intention than developed countries. However, the perception of status of those who undertake a business venture is greater in developed countries, that is, even with a greater entrepreneurial intention, the developing countries still do not see this career as not so promising.

Also in this sense, it was possible to observe that, for developing countries, starting a new business is regarded as a desirable career option. In addition, it was possible to observe that among the developing countries the entrepreneurial intention was different, that is to say, although they are developing countries that stand out economically, they do not behave in a similar way as the entrepreneurial intention. Finally, with respect to gender, it advances with the result that men undertake business ventures more than women do. As a possible answer to this result, it was found that women even seeing their career as promising are more afraid to undertake a business venture. 


\section{THEORETICAL BASIS}

Differences in entrepreneurship in developed and developing countries

The world economy after the crisis of international change in 1971 had to organize itself and after a series of meetings between the main economies of the time, in 1976 the G7 was created, group formed by Great Britain, France, Germany, the USA, Japan, Italy and Canada (WAHEEDUZZAMAN, 2011; MOSTAFA; MAHMOOD, 2015; SMALES et al., 2020). However, these countries are not the only ones that have influenced the world economy over the years, according to the World Development Indicators of 2014, the BRICS countries (Brazil, Russia, India, China and Africa) represent more than $40 \%$ of the world population and around $25 \%$ of the world GDP, constituting a significant growth over the years (NADEEM et al., 2017). In this way, studies have sought to understand the evolution potential of BRICS in comparison with the G7, for example, the study by Mostafa and Mahmood (2015), identified that the BRICS have the potential to surpass the G7 in the long term, but should not be as easy as presumed by some economists, since several uncertainty variables can slow this growth.

When comparing the countries of these two groups, it is possible to observe that the economy in developed countries has a characteristic of stability in its market relations, which makes it possible to organize a career based on the type of profession, market or area that it intends to operate (IAKOVLEVA et al., 2007). However, developing countries are known to be unstable, where markets are still in the process of regulation and accommodation, i.e., the creation of sound markets (BEZGODOV, 1999). Based on this scenario, the entrepreneurial career option becomes a viable option, since it allows flexibility and an alternative of economic gain. This perspective allows us to imagine that, in general, in developing countries, this entrepreneurial intention may have greater presence than in developed countries (BRUTON et al., 2008; MORAES et al., 2018). Thus, the present study proposes the following hypothesis:

H1: the entrepreneurial intention in developing countries will be statistically higher than in developed countries.

\section{Entrepreneurship in developing countries}

BRICS is an association of five emerging economies in the world. The term BRIC was later reformulated as BRICS with the inclusion of South Africa in 2010. This group was formulated as potential countries that would exceed the G7 countries by the year 2020 (NADEEM et al., 2017). In this sense, the study by Ardichvili et al. (2012) analyzed the development of human capital in these countries and identified that in terms of the current capacity of human capital, Russia and Brazil are ahead of China and India.

Along with the capacity of human capital, the entrepreneurial capacity of a country consequently results in the economic development of the same, being able to be a factor of growth and opening of opportunities. This phenomenon intensifies in the case of developing countries, that is, those that suffer from unstable markets and high levels of social inequality (ACS, 2006). In this sense, studies have focused on analyzing entrepreneurship as a key to the growth of developing countries, such as encouraging entrepreneurial activity in each country (GHANEM, 2013; RATTEN, 2014; PECLY; RIBEIRO, 2020).

In the article by Solhi and Rahmanian (2016), it is possible to observe how some factors are explored with greater intensity in the developing countries. In this case, the authors explored that the term innovation does not necessarily mean innovation as it is understood in the levels of developed countries, since in the 
organizational or structural innovation it would already be considered innovation. In addition to these specific characteristics of developing countries, we need to understand how each country develops its economy and the differences between them. Avnimelech, et al. (2014) and Pecly and Ribeiro (2020) show that the specific economic characteristics of the country can influence the entrepreneurial profile of population. Thus, the present study corroborates in the following hypothesis:

H2: entrepreneurial intention among developing countries will be statistically different from each other.

\section{Gender Entrepreneurship}

Studies on entrepreneurship have been the focus of researchers who have seen the phenomenon in a variety of ways, from an economic approach with Schumpeter (2017) to a behavioral and managerial approach with Drucker (1986). However, in the last few years research has moved the lens to the behavior and profile that entrepreneurs possess and the reasons that lead them to undertake a business venture (PABLO-MARTÍ et al., 2014; LAURE; DREW, 2010). The study by Krakauer et al. (2018) proposes precisely to understand the entrepreneurial profile of Brazilian women, because the entrepreneurial market in Brazil is in great expansion and with women being one of the factors that justify this increase. To be exact, according to the IBGE (2017), $14 \%$ of the Brazilian population owns its own business, equivalent to approximately 29 million people.

Previous studies (DAVIS; LONG, 1999; BASTIAN; ZALI, 2016) show that to start a business, women and men have essentially the same critical needs; however, despite similar needs, other studies, such as Verheul et al. (2012), Shinnar et al. (2012), Meyer (2018) and Meyer and Hamilton (2020), show that the reasons that lead women to undertake a business venture differ substantially from the entrepreneurial intention of men. As for the differentiation used for men and women, it was based on the GEM report (2014), where the gender of the interviewee is questioned. In this way, it is possible to distinguish and analyze the data, enabling the comparative analysis of entrepreneurial intention between the male and female genders. Thus, studies are necessary to identify the entrepreneurial profile of men and women, in order to analyze if they have differences or similarities, so the present study proposes the following hypothesis:

H3: the entrepreneurial intention of the male profile in developing countries will be statistically higher than the female profile.

\section{METHODOLOGY}

In order to reach the objective of investigating a possible difference in entrepreneurial intention between developed and developing countries, we used the Global Entrepreneurship Monitor (GEM) database in this study, which provides secondary and treated data for the purpose of promoting research, entrepreneurial activity in several countries. The most recent data from the Adult Population Survey (APS), published in the year 2014 (GEM), were used to examine the characteristics, motivations and ambitions of individuals starting a business, as well as social attitudes towards entrepreneurship.

The data are collected in each country by a specialized company that conducts telephone or personal interviews with the adult population, allowing a view of entrepreneurial behavior and attitudes at the country level, and provides support for comparisons with other countries to be made.We defined the intentional sample based on two groups: developed countries belonging to the G7 and developing countries, belonging to BRICS, totaling 20,970 respondents. To better meet the proposed objective, we selected variables that had better identified the entrepreneurial intention in the countries analyzed. 
For each Hypothesis tested, we presented the descriptive results and, later, to compare the distribution of the groups under analysis, we used non-parametric statistics, since they are categorical variables. Thus, in order to test Hypotheses 1 and 3, we used the Mann-Whitney test for two independent categorical samples and to test Hypothesis 2, we used the KruskalWallis test, since it was the analysis of the distribution of more than two independent samples (MARÔCO, 2010). We performed data analysis using the IBM SPSS Statistics, 25.

\section{RESULTS}

At first, we wer able to identify the existence of a possible difference in the entrepreneurial intention between developed and developing countries, according to some variables considered important to describe the phenomenon, as Table 1 below:

Table 1 - Difference in Entrepreneurial Intention between Developed and Developing Countries

\begin{tabular}{|c|c|c|c|c|c|c|}
\hline \multirow{2}{*}{\multicolumn{2}{|c|}{ Variable }} & \multirow{2}{*}{$\begin{array}{l}\text { Developed } \\
\text { number of } \\
\text { respondents }\end{array}$} & \multicolumn{3}{|c|}{ Developing } & \multirow[b]{2}{*}{ Total } \\
\hline & & & $\%$ & $\begin{array}{l}\text { number of } \\
\text { respondents }\end{array}$ & $\%$ & \\
\hline \multicolumn{2}{|c|}{$\begin{array}{l}\text { Knowledge, skill and experience needed to start a new } \\
\text { business. }\end{array}$} & 7076 & $43 \%$ & 9254 & $57 \%$ & 16330 \\
\hline \multicolumn{2}{|c|}{$\begin{array}{l}\text { Fear of failure would prevent you from starting a } \\
\text { business. }\end{array}$} & 7410 & $47 \%$ & 8487 & $53 \%$ & 15897 \\
\hline \multicolumn{2}{|c|}{$\begin{array}{l}\text { In my country, most people consider starting a new } \\
\text { business a desirable career choice. }\end{array}$} & 9341 & $55 \%$ & 7794 & $45 \%$ & 17135 \\
\hline \multicolumn{2}{|c|}{$\begin{array}{l}\text { In my country, those who can start a new business have } \\
\text { a high level of status and respect. }\end{array}$} & 12499 & $60 \%$ & 8471 & $40 \%$ & 20970 \\
\hline \multicolumn{2}{|c|}{$\begin{array}{l}\text { You are, alone or with other people, currently trying to } \\
\text { start a new business, including any self-employment or } \\
\text { selling goods or services to others. }\end{array}$} & 1545 & $37 \%$ & 2604 & $63 \%$ & 4149 \\
\hline \multicolumn{2}{|c|}{$\begin{array}{l}\text { In the last twelve months, you've done something to } \\
\text { help start a new business. }\end{array}$} & 1357 & $49 \%$ & 1430 & $51 \%$ & 2787 \\
\hline \multirow{2}{*}{$\begin{array}{l}\text { Are you involved in this } \\
\text { start-up to take advantage } \\
\text { of a business opportunity or } \\
\text { because you have no better } \\
\text { job choices? }\end{array}$} & Opportunity & 671 & $49 \%$ & 689 & $51 \%$ & 1360 \\
\hline & No better choices & 148 & $29 \%$ & 357 & $71 \%$ & 505 \\
\hline \multirow{3}{*}{$\begin{array}{l}\text { Which do you think is the } \\
\text { most important reason for } \\
\text { seeking this opportunity? }\end{array}$} & Greater independence & 374 & $51 \%$ & 362 & $49 \%$ & 736 \\
\hline & $\begin{array}{l}\text { Increase personal } \\
\text { income }\end{array}$ & 253 & $39 \%$ & 398 & $61 \%$ & 651 \\
\hline & Just to maintain income & 77 & $53 \%$ & 68 & $47 \%$ & 145 \\
\hline
\end{tabular}

Source: own elaboration.

On the basis of the above results, it is possible to observe in general a greater entrepreneurial intention of the developing countries in relation to the developed countries, based on the analyzed variables. There are some exceptions where the difference favors developed countries, it would be the notion that starting a new business is regarded in the country as a desirable career choice $(55 \%)$; the perception that starting a new business generates a high level of status and respect $(60 \%)$; greater independence $(51 \%)$ and; Maintaining income $(53 \%)$ as factors to 
pursue a business opportunity. These findings are important because, even with scenarios of greater uncertainty and instability, developing countries have a greater margin for growth and this targeting opens the door to enterprising careers (IAKOVLEVA et al., 2007; BEZGODOV, 1999; BRUTON et al., 2008).
To test whether such differences are statistically significant, the Mann-Whitney statistical test was performed to test Hypothesis 1 of the study that there is a difference between developed and developing countries in the distribution of the variables of entrepreneurial intention. The results are shown in Table 2 .

Table 2 - Mann-Whitney test to analyze the existence of differences between groups

\begin{tabular}{|c|c|c|c|c|}
\hline \multicolumn{2}{|l|}{ Variable } & Coefficient & $\mathbf{Z}$ & $\mathbf{p}$ \\
\hline \multicolumn{2}{|c|}{ Knowledge, skill and experience needed to start a new business. } & 193263212.000 & -3.375 & $.001 * *$ \\
\hline \multicolumn{2}{|c|}{ Fear of failure would prevent you from starting a business. } & 185003587.500 & -7.481 & $.000 * * *$ \\
\hline \multicolumn{2}{|c|}{$\begin{array}{l}\text { In my country, most people consider starting a new business a } \\
\text { desirable career choice. }\end{array}$} & 89101372.000 & -18.844 & $.000 * * *$ \\
\hline \multicolumn{2}{|c|}{$\begin{array}{l}\text { In my country, those who can start a new business have a high } \\
\text { level of status and respect. }\end{array}$} & 100457347.500 & -4.374 & $.000 * * *$ \\
\hline \multicolumn{2}{|c|}{$\begin{array}{l}\text { You are, alone or with other people, currently trying to start a } \\
\text { new business, including any self-employment or selling goods } \\
\text { or services to others. }\end{array}$} & 198993984.000 & -9.564 & $.000 * * *$ \\
\hline \multicolumn{2}{|c|}{$\begin{array}{l}\text { In the last twelve months, you've done something to help start a } \\
\text { new business. }\end{array}$} & 2377156.500 & -13.022 & $.000 * * *$ \\
\hline \multirow{2}{*}{$\begin{array}{l}\text { Are you involved in this start-up to } \\
\text { take advantage of a business } \\
\text { opportunity or because you have no } \\
\text { better job choices? }\end{array}$} & Opportunity & 585939.500 & -5.506 & $.000 * * *$ \\
\hline & No better choices & 571705.500 & -7.806 & $.000 * * *$ \\
\hline \multirow{3}{*}{$\begin{array}{l}\text { Which do you think is the most } \\
\text { important reason for seeking this } \\
\text { opportunity? }\end{array}$} & Greater independence & 287802.500 & -2.688 & $.007 *$ \\
\hline & $\begin{array}{l}\text { Increase personal } \\
\text { income }\end{array}$ & 265981.000 & -5.565 & $.000 * * *$ \\
\hline & Just to maintain income & 301985.000 & -1.493 & .135 \\
\hline
\end{tabular}

Source: own elaboration.

Notes: $* * *$ statistical significance at the level of $1 \%, * *$ at $5 \%$ and $*$ at $10 \%$.

According to the results presented, the null hypothesis of the Mann-Whitney test is rejected. Therefore, it can be inferred that there are statistically significant differences between developed and developing countries regarding entrepreneurial intention, with the exception of the "Just to maintain income" variable, which did not present statistical significance. Based on the evidence, we cannot reject Hypothesis 1 of the study that entrepreneurial intention in developing countries is statistically higher than in developed countries.

Once greater entrepreneurial intent was observed in developing countries, we sought to analyze if there is a difference in the distribution among BRICS countries, according to the results presented in Table 3. It is worth noting that, for two of the variables (which are in Table 3), the GEM database did not provide figures for Brazil. 
Table 3 - Difference in Entrepreneurial Intent Among Developing Countries (BRICS)

\begin{tabular}{|c|c|c|c|c|c|c|c|c|c|c|c|c|}
\hline \multirow{2}{*}{\multicolumn{2}{|c|}{ Variable }} & \multicolumn{2}{|c|}{ Brazil } & \multicolumn{2}{|c|}{ Russia } & \multicolumn{2}{|c|}{ India } & \multicolumn{2}{|c|}{ China } & \multicolumn{2}{|c|}{ South Africa } & \multirow[b]{2}{*}{ TOTAI } \\
\hline & & $\mathbf{N}^{\mathbf{o}}$ & $\%$ & $\mathbf{N}^{\mathbf{o}}$ & $\%$ & $\mathbf{N}^{\mathbf{o}}$ & $\%$ & $\mathbf{N}^{\mathbf{o}}$ & $\%$ & $\mathbf{N}^{\mathbf{o}}$ & $\%$ & \\
\hline \multicolumn{2}{|c|}{ Knowledge, skill and experience needed to start a new business. } & 4957 & 53.57 & 522 & 5.64 & 1239 & 13.39 & 1111 & 12.01 & 1425 & 15.40 & 9254 \\
\hline \multicolumn{2}{|c|}{ Fear of failure would prevent you from starting a business. } & 4229 & 49.83 & 820 & 9.66 & 1257 & 14.81 & 1177 & 13.87 & 1004 & 11.83 & 8487 \\
\hline \multicolumn{2}{|c|}{$\begin{array}{l}\text { In my country, most people consider starting a new business a } \\
\text { desirable career choice. }\end{array}$} & - & & 1181 & 15.15 & 1747 & 22.41 & 2249 & 28.86 & 2617 & 33.58 & 7794 \\
\hline \multicolumn{2}{|c|}{$\begin{array}{l}\text { In my country, those who can start a new business have a high } \\
\text { level of status and respect. }\end{array}$} & - & & 1181 & 13.94 & 2022 & 23.87 & 2561 & 30.23 & 2707 & 31.96 & 8471 \\
\hline \multicolumn{2}{|c|}{$\begin{array}{l}\text { You are, alone or with other people, currently trying to start a new } \\
\text { business, including any self-employment or selling goods or } \\
\text { services to others. }\end{array}$} & 895 & 34.37 & 91 & 3.49 & 317 & 12.17 & 899 & 34.52 & 402 & 15.44 & 2604 \\
\hline \multicolumn{2}{|c|}{$\begin{array}{l}\text { In the last twelve months, you've done something to help start a } \\
\text { new business. }\end{array}$} & 421 & 29.44 & 81 & 5.66 & 151 & 10.56 & 617 & 43.15 & 160 & 11.19 & 1430 \\
\hline \multirow{2}{*}{$\begin{array}{l}\text { Are you involved in this start-up to take } \\
\text { advantage of a business opportunity or because } \\
\text { you have no better job choices? }\end{array}$} & Opportunity & 286 & 41.51 & 33 & 4.79 & 65 & 9.43 & 240 & 34.83 & 65 & 9.43 & 689 \\
\hline & $\begin{array}{l}\text { No better } \\
\text { choices }\end{array}$ & 69 & 19.33 & 25 & 7.00 & 47 & 13.17 & 172 & 48.18 & 44 & 12.32 & 357 \\
\hline \multirow{3}{*}{$\begin{array}{l}\text { Which do you think is the most important } \\
\text { reason for seeking this opportunity? }\end{array}$} & $\begin{array}{l}\text { Greater } \\
\text { independence }\end{array}$ & 197 & 54.42 & 12 & 3.31 & 9 & 2.49 & 94 & 25.97 & 50 & 13.81 & 362 \\
\hline & $\begin{array}{l}\text { Increase } \\
\text { personal income }\end{array}$ & 107 & 26.88 & 18 & 4.52 & 58 & 14.57 & 181 & 45.48 & 34 & 8.54 & 398 \\
\hline & $\begin{array}{l}\text { Just to maintain } \\
\text { income }\end{array}$ & 12 & 17.65 & 2 & 2.94 & 16 & 23.53 & 26 & 38.24 & 12 & 17.65 & 68 \\
\hline
\end{tabular}

Source: own elaboration. 
The results reveal differences among developing countries with respect to the entrepreneurs' intention on the part of the respondents. It is possible to observe that, among the countries, there is a greater difference between Brazil (53.57\%) and Russia (5.64\%) as to the knowledge, skill and experience necessary to start a new business on the part of the interviewee. As for the fear of failure, Brazilian are pointed out as the most fearful $(49.83 \%)$ in contrast also with Russians (9.66\%). Starting a business is seen as a desirable career choice mainly for South Africa (31.96\%), contrasting mainly with Russia (13.94\%). In the Brazilian reality, economic instability seems to aggravate this feeling, especially among women who intend to undertake (CAMARGO et al, 2018). As for Russians, these are among those interviewed in developing countries who have tried the least to start a business $(3.49 \%)$ and who have helped start a new business $(5.66 \%)$ differently from China, 34, 52\% and $43.15 \%$, respectively. Brazil stands out as being involved in a start-up as an opportunity (41.51\%) in contrast to Russia (4.79\%). These Russian entrepreneurs are less involved in a start-up for lack of opportunity $(7 \%)$ than the Chinese
(48.18\%), which appears as the biggest motivation for these entrepreneurs. Brazilians see a business opportunity as a way to gain more independence, unlike Russians (3.31\%). Chinese see the business opportunity mainly as a way to increase $(45.48 \%)$ and maintain income (38.24\%), again in contrast to Russians, $4.52 \%$ and $2.94 \%$, respectively.

These results are in agreement with the contributions of other studies in that although developing countries have greater entrepreneurial intention, countries have unique characteristics (SOLHI; RAHMANIAN, 2016). In this way, it is not possible to group all developing countries together, but rather to analyze the scenarios and actions for the growth of entrepreneurship in the region (GHANEM, 2013; RATTEN, 2014).

To test the differences between developing countries are statistically significant, we performed the KruskalWallis statistical test in order to test Hypothesis 2 of the study, that there is difference between developed countries in the distribution of the variables of entrepreneurial intention. The results are shown in Table 4.

Table 4 - Kruskal-Wallis test to analyze the existence of difference between developing countries.

\begin{tabular}{|c|c|c|c|}
\hline Variable & Kruskal-Wallis & df & p \\
\hline Knowledge, skill and experience needed to start a new business. & 577.155 & 4 & $.000 * * *$ \\
\hline Fear of failure would prevent you from starting a business. & 326.516 & 4 & $.000 * * *$ \\
\hline $\begin{array}{l}\text { In my country, most people consider starting a new business a } \\
\text { desirable career choice. }\end{array}$ & 123.944 & 3 & $.000 * * *$ \\
\hline $\begin{array}{l}\text { In my country, those who can start a new business have a high } \\
\text { level of status and respect. }\end{array}$ & 77.459 & 3 & $.000 * * *$ \\
\hline $\begin{array}{l}\text { You are, alone or with other people, currently trying to start a } \\
\text { new business, including any self-employment or selling goods } \\
\text { or services to others. }\end{array}$ & 805.181 & 4 & $.000 * * *$ \\
\hline $\begin{array}{l}\text { In the last twelve months, you've done something to help start a } \\
\text { new business. }\end{array}$ & 121.267 & 4 & $.000 * * *$ \\
\hline $\begin{array}{l}\text { Are you involved in this start-up to } \\
\text { take advantage of a business }\end{array}$ & 59.091 & 4 & $.000 * * *$ \\
\hline $\begin{array}{l}\text { opportunity or because you have no } \\
\text { better job choices? }\end{array}$ & 40.187 & 4 & $.000 * * *$ \\
\hline
\end{tabular}




\begin{tabular}{|c|c|c|c|c|}
\hline & Greater independence & 103.902 & 4 & $.000 * * *$ \\
\hline \multirow[t]{2}{*}{$\begin{array}{l}\text { Which do you think is the most } \\
\text { important reason for seeking this } \\
\text { opportunity? }\end{array}$} & $\begin{array}{l}\text { Increase personal } \\
\text { income }\end{array}$ & 64.982 & 4 & $.000 * * *$ \\
\hline & Just to maintain income & 23.803 & 4 & $.000 * * *$ \\
\hline
\end{tabular}

Source: own elaboration.

Notes: ${ }^{* * *}$ statistical significance at the level of $1 \%$.

According to the presented results, the null hypothesis of the Kruskal-Wallis test is rejected. Thus, it can be inferred that there are statistically significant differences between developed and developing BRICS countries, so that one cannot reject Hypothesis 2 of the study that entrepreneurial intent is different among developing countries. To identify statistically between which groups of countries are the distribution differences, we performed a paired analysis in a post hoc test. Table 5 below shows the pairs whose differences were statistically significant.

Table 5 - Peers among developing countries with statistically significant difference between variables of entrepreneurial intention.

\begin{tabular}{|c|c|c|}
\hline \multicolumn{2}{|l|}{ Variable } & Pairs * \\
\hline \multicolumn{2}{|c|}{$\begin{array}{l}\text { Knowledge, skill and experience needed to start a new } \\
\text { business. }\end{array}$} & $\begin{array}{l}\text { Russia-China; Russia-India; Russia- South Africa; } \\
\text { Russia-Brazil; China-India; China-South Africa; } \\
\text { China-Brazil; India-Brazil; South Africa -Brazil. }\end{array}$ \\
\hline \multicolumn{2}{|c|}{$\begin{array}{l}\text { Fear of failure would prevent you from starting a } \\
\text { business. }\end{array}$} & $\begin{array}{l}\text { Russia-China; Russia-India; Russia- South Africa; } \\
\text { China-India; China-South Africa; China-Brazil; } \\
\text { India- South Africa; South Africa -Brazil. }\end{array}$ \\
\hline \multicolumn{2}{|c|}{$\begin{array}{l}\text { In my country, most people consider starting a new } \\
\text { business a desirable career choice. }\end{array}$} & $\begin{array}{l}\text { Russia-India; } \\
\text { China-India; China-South Africa; } \\
\text { India- South Africa; India-Brazil; South Africa- } \\
\text { Brazil. }\end{array}$ \\
\hline \multicolumn{2}{|c|}{$\begin{array}{l}\text { In my country, those who can start a new business have } \\
\text { a high level of status and respect. }\end{array}$} & $\begin{array}{l}\text { Russia-China; Russia- South Africa; Russia-Brazil } \\
\text { China-India; China-Brazil; India- South Africa; India- } \\
\text { Brazil; South Africa -Brazil. }\end{array}$ \\
\hline \multicolumn{2}{|c|}{$\begin{array}{l}\text { You are, alone or with other people, currently trying to } \\
\text { start a new business, including any self-employment or } \\
\text { selling goods or services to others. }\end{array}$} & $\begin{array}{l}\text { Russia-China; Russia-India; Russia-South Africa; } \\
\text { Russia-Brazil; China-India; China-South Africa; } \\
\text { China-Brazil; South Africa-Brazil. }\end{array}$ \\
\hline \multicolumn{2}{|c|}{$\begin{array}{l}\text { In the last twelve months, you've done something to } \\
\text { help start a new business. }\end{array}$} & $\begin{array}{l}\text { Russia-China; Russia-India; Russia-South Africa; } \\
\text { China-India; China-South Africa; China-Brazil; } \\
\text { India-Brazil; South Africa -Brazil. }\end{array}$ \\
\hline \multirow{2}{*}{$\begin{array}{l}\text { Are you involved in this start-up to } \\
\text { take advantage of a business } \\
\text { opportunity or because you have no } \\
\text { better job choices? }\end{array}$} & Opportunity & $\begin{array}{l}\text { Russia-Brazil; China-Brazil; India-Brazil; South } \\
\text { Africa-Brazil. }\end{array}$ \\
\hline & $\begin{array}{l}\text { No better } \\
\text { choices }\end{array}$ & $\begin{array}{l}\text { Russia-Brazil; China-Brazil; India-Brazil; South } \\
\text { Africa-Brazil. }\end{array}$ \\
\hline \multirow{3}{*}{$\begin{array}{l}\text { Which do you think is the most } \\
\text { important reason for seeking this } \\
\text { opportunity? }\end{array}$} & $\begin{array}{l}\text { Greater } \\
\text { independence }\end{array}$ & $\begin{array}{l}\text { Russia-Brazil; China-India; China-South Africa; } \\
\text { China-Brazil; India-South Africa; India-Brazil. }\end{array}$ \\
\hline & $\begin{array}{l}\text { Increase } \\
\text { personal income }\end{array}$ & $\begin{array}{l}\text { China-Brazil; India-Brazil; China-South Africa; } \\
\text { India-South Africa. }\end{array}$ \\
\hline & maintain & China-India; India-Brazil. \\
\hline
\end{tabular}

Source: own elaboration.

Notes: * statistically significant difference at the level of $5 \%$ 
Finally, in order to understand the entrepreneurial profile regarding gender, we sought to investigate the existence of a possible difference in the entrepreneurial intention between male and female, according to Table 6 below:

Table 6 - Difference in the entrepreneurial intention between male and female.

\begin{tabular}{|c|c|c|c|c|c|}
\hline \multirow[b]{2}{*}{ Variável } & \multicolumn{2}{|l|}{ Male } & \multicolumn{2}{|c|}{ Female } & \multirow[b]{2}{*}{ TOTAL } \\
\hline & $\begin{array}{l}\text { number of } \\
\text { respondents }\end{array}$ & $\%$ & $\begin{array}{l}\text { number of } \\
\text { respondents }\end{array}$ & $\%$ & \\
\hline $\begin{array}{l}\text { Knowledge, skill and experience needed to start a } \\
\text { new business. }\end{array}$ & 13306 & 64.97 & 7174 & 35.03 & 20480 \\
\hline $\begin{array}{l}\text { Fear of failure would prevent you from starting a } \\
\text { business. }\end{array}$ & 7033 & 44.24 & 8864 & 55.76 & 15897 \\
\hline $\begin{array}{l}\text { In my country, most people consider starting a new } \\
\text { business a desirable career choice. }\end{array}$ & 8600 & 50.19 & 8535 & 49.81 & 17135 \\
\hline $\begin{array}{l}\text { In my country, those who can start a new business } \\
\text { have a high level of status and respect. }\end{array}$ & 10390 & 49.55 & 10580 & 50.45 & 20970 \\
\hline $\begin{array}{l}\text { You are, alone or with other people, currently trying } \\
\text { to start a new business, including any self- } \\
\text { employment or selling goods or services to others. }\end{array}$ & 2363 & 56.95 & 1786 & 43.05 & 4149 \\
\hline $\begin{array}{l}\text { In the last twelve months, you've done something to } \\
\text { help start a new business. }\end{array}$ & 1655 & 59.38 & 1132 & 40.62 & 2787 \\
\hline \multirow{2}{*}{$\begin{array}{l}\text { Are you involved in this } \\
\text { start-up to take } \\
\text { advantage of a business } \\
\text { opportunity or because } \\
\text { you have no better job } \\
\text { choices? }\end{array}$} & 836 & 61.47 & 524 & 38.53 & 1360 \\
\hline & 278 & 50.09 & 227 & 40.90 & 555 \\
\hline \multirow{3}{*}{$\begin{array}{l}\text { Which do you think is } \\
\text { the most important } \\
\text { reason for seeking this } \\
\text { opportunity? }\end{array}$} & 437 & 59.38 & 299 & 40.63 & 736 \\
\hline & 394 & 60.52 & 257 & 39.48 & 651 \\
\hline & 92 & 63.45 & 53 & 36.55 & 145 \\
\hline
\end{tabular}

Source: own elaboration.

The descriptive results above, about the gender of the people interviewed, reveal that, in general, the masculine gender stands out regarding the entrepreneurial intention, considering the variables analyzed in this study, with the exception of fear of failure to start a business, which is greater among the women interviewed, revealing that men are more fearless in this area. The other exception concerns the women's perception that starting a business generates a high level of status and respect in the country they inhabit.

The results of this study corroborate previous studies by Verheul et al. (2012) and Shinnar et al. (2012), since they show that there is a difference in entrepreneurship between men and women, even though according to Davis and Long (1999) the two have similar entrepreneurial needs. More specifically in the Brazilian reality, women face fear related to the future of the company and the business; sector-specific fears; fears related to financial aspects and economic instability (CAMARGO et al., 2018).

To test whether such differences are statistically significant, we performed the Mann-Whitney statistical test in order to test Hypothesis 3 of the study that there is a difference between male and female genders regarding entrepreneurial intention. The results can be seen in Table 7 . 
Table 7 - Mann-Whitney test to analyze the existence of difference between male and female.

\begin{tabular}{|c|c|c|c|c|}
\hline \multicolumn{2}{|l|}{ Variable } & Coefficient & $\mathbf{Z}$ & $\mathbf{P}$ \\
\hline \multicolumn{2}{|c|}{ Knowledge, skill and experience needed to start a new business. } & 174631299,500 & -24.820 & $.000 * * *$ \\
\hline \multicolumn{2}{|c|}{ Fear of failure would prevent you from starting a business. } & 180256976,500 & -14.856 & $.000 * * *$ \\
\hline \multicolumn{2}{|c|}{$\begin{array}{l}\text { In my country, most people consider starting a new business a } \\
\text { desirable career choice. }\end{array}$} & 101404250,000 & -3.597 & $.000 * * *$ \\
\hline \multicolumn{2}{|c|}{$\begin{array}{l}\text { In my country, those who can start a new business have a high } \\
\text { level of status and respect. }\end{array}$} & 105008761,000 & -2.017 & $.044^{*}$ \\
\hline \multicolumn{2}{|c|}{$\begin{array}{l}\text { You are, alone or with other people, currently trying to start a } \\
\text { new business, including any self-employment or selling goods or } \\
\text { services to others. }\end{array}$} & 200466142,000 & -11.334 & $.000 * * *$ \\
\hline \multicolumn{2}{|c|}{$\begin{array}{l}\text { In the last twelve months, you've done something to help start a } \\
\text { new business. }\end{array}$} & 2851717,500 & -2.421 & $.015^{*}$ \\
\hline \multirow{2}{*}{$\begin{array}{l}\text { Are you involved in this start-up to } \\
\text { take advantage of a business } \\
\text { opportunity or because you have no } \\
\text { better job choices? }\end{array}$} & Opportunity & 608376,000 & -2.869 & $.004 * *$ \\
\hline & No better choices & 623854,500 & -2.049 & $.040 *$ \\
\hline \multirow{3}{*}{$\begin{array}{l}\text { Which do you think is the most } \\
\text { important reason for seeking this } \\
\text { opportunity? }\end{array}$} & Greater independence & 290719,000 & -.745 & .456 \\
\hline & Increase personal income & 295547,000 & -.113 & .910 \\
\hline & Just to maintain income & 292871,000 & -.799 & .424 \\
\hline
\end{tabular}

Source: own elaboration.

Notes: *** statistical significance at the level of $1 \%, * *$ at $5 \%$ and $*$ at $10 \%$.

According to the results presented, the null hypothesis of the Mann-Whitney test is rejected, except for the variables "Greater Independence", "Increase Income" and "Maintain Income". Therefore, it can be inferred that, for the other variables, there are statistically significant differences between the genders regarding the entrepreneurial intention, so that we cannot reject Hypothesis 3 of the study that the entrepreneurial intention of the male gender is greater than the entrepreneurial intention of the female gender.

\section{CONCLUSION}

The objective of the present study was to investigate a possible difference in entrepreneurial intention between developed and developing countries. To do so, we used data from the year 2014 - most recently published by the GEM - of the Adult Population Survey (APS). The intentional sample was defined based on developed G7 and developing countries belonging to the BRICS. Moreover, to better meet the proposed objective, we selected variables that best identify the entrepreneurial intention in the countries analyzed.

The results revealed that there is a statistically significant difference in entrepreneurial intention between developed and developing countries, the latter being the ones they most intend to undertake a business venture. However, according to the findings, starting a new business is regarded more as a desirable career choice and worthy of high status and respect in developed countries, revealing that although they are not ahead in starting a business, it is in those countries where those who are headed for this career are most esteemed.

Among the BRICS developing countries, there was also a statistically significant difference between them in entrepreneurial intention, revealing that the 
emerging countries considered most prominent in their development, have different entrepreneurship profiles, which should be investigated further, as great disparities in the entrepreneurial perception among emerging countries that excel in the economy, such as Brazil and Russia, for example.

The descriptive results reveal that, in general, the masculine gender stands out as the entrepreneurial intention, considering the variables analyzed in this study, with the exception of the fear of failure to start a business, which is more common among women interviewed, revealing that men are more fearless in this area. The other exception concerns the women's perception that starting a business generates a high level of status and respect in the country they inhabit.

Regarding the limitations of the study, data corresponding to only one year were observed, which restricts the inference of the results. Thus, other studies may seek data from other years and study them over time, in order to observe the evolution of the entrepreneurial intention in the countries analyzed. Another limitation that refers to the data provided by the GEM, refers to the year of publication, the most recent data being for the year 2014. Continuing, GEM data has some weaknesses, such as the lack of some variables on Brazil.

This study has analyzed the issue of gender in a generalized way among the countries; however, future studies can analyze this perspective individually. As a further suggestion, future research could relate the results presented here with country development indexes, in order to justify the presented differences.

\section{REFERENCES}

ACS, Z. How is entrepreneurship good for economic growth?. Innovations: technology,

governance, globalization, v.1, n.1, p. 97-107, 2006.

ARDICHVILI, A.; JONDLE, D.; KOWSKE, B.; CORNACHIONE, E.; LI, J.; THAKADIPURAM, T. Ethical cultures in large business organizations in Brazil, Russia, India, and China. Journal of Business Ethics, v.105, n.4, p. 415-428, 2012.

AVNIMELECH, G.; ZELEKHA, Y.; SHARABI, E. (2014). The effect of corruption on entrepreneurship in developed vs non-developed countries. International Journal of Entrepreneurial Behavior \& Research, v.20, n.3, p. 237-262, 2014.

BASTIAN, B. L.; ZALI, M. R. Entrepreneurial motives and their antecedents of men and women in North Africa and the Middle East. Gender in Management: An International Journal, v.31, n.7, p.456-478, 2016.

BEZGODOV, A. Entrepreneurship Sociology, Petropolis, St Petersburg, 1999.

BRUTON, G. D.; AHLSTROM, D.; OBLOJ, K. Entrepreneurship in emerging economies: Where are we today and where should the research go in the future. Entrepreneurship theory and practice, v.32, n.1, p. 1-14, 2008.

CAMARGO, R. A. M. M.; LOURENÇO, M. L.; FERREIRA, J. M. Mulheres empreendedoras no Brasil: quais seus medos?. Revista Brasileira de Gestão de Negócios, v. 20, n. 2, p. 178-193, 2018.

DAVIS, S. E. M; LONG, D. D. Women Entrepreneurs: What Do They Need?, Business and Economic Review, v.45, n. 4, p. 25-26, 1999. 
DRUCKER, P. F. Management: Tasks, responsibilities, practices. truman talley Books, 1986.

GHANEM, H. Role of micro and small enterprises in Egypt's economic transition. Brookings, 2013.

IAKOVLEVA, T.; KOLVEREID, L.; STEPHAN, U. Entrepreneurial intentions in developing and developed countries. Education+ Training, v.53, n.5, p. 353-370, 2011.

KRAKAUER, P. V. D. C.; DE MORAES, G. H. S. M.; CODA, R.; BERNE, D. D. F. Brazilian women's entrepreneurial profile and intention. International Journal of Gender and Entrepreneurship, v.10, n.4, p. 361-380, 2018.

LAURE HUMBERT, A.; DREW, E. Gender, entrepreneurship and motivational factors in an Irish context. International Journal of Gender and Entrepreneurship, v.2, n.2, p. 173-196, 2010.

MARÔCO, J. Análise estatística com o PASW Statistics (ex-SPSS). Report Number: Pêro Pinheiro, 2010.

MEYER, N. Research on female entrepreneurship: Are we doing enough? Polish Journal of Management Studies, v. 17, n. 2, p. 158-169, 2018.

MEYER, N.; HAMILTON, L.. Female entrepreneurs'business training and its effect on various entrepreneurial factors: Evidence from a developing country. International Journal of Economics and Finance Studies, v. 12, n. 1, p. 135-151, 2020.

MORAES, G. H. S. M.; IIZUKA, E. S.; PEDRO, M. Effects of entrepreneurial characteristics and university environment on entrepreneurial intention. Revista de Administração Contemporânea, v. 22, n. 2, p. 226-248, 2018.

MOSTAFA, G.; MAHMOOD, M. The rise of the BRICS and their challenge to the G7. International Journal of Emerging Markets, v.10, n.1, p.156-170, 2015.

NADEEM, M.; GAN, C.; NGUYEN, C. Does intellectual capital efficiency improve firm performance in BRICS economies? A dynamic panel estimation. Measuring Business Excellence, v.21, n. 1, p. 65-85, 2017.

PABLO-MARTÍ, F.; GARCÍATABUENCA, A.; LUIS CRESPOESPERT, J. Do gender-related differences exist in Spanish entrepreneurial activities?. International Journal of Gender and Entrepreneurship, v.6, n.2, p.200-214, 2014.

PIPEROPOULOS, P. Ethnic female business owners: more female or more ethnic entrepreneurs. Journal of small business and enterprise development, v.19, n.2, p.192-208, 2012.

RATTEN, V. Encouraging collaborative entrepreneurship in developing countries: the current challenges and a research agenda. Journal of Entrepreneurship in Emerging Economies, v.6, n.3, p.298-308, 2014.

SCHUMPETER, J. A. Theory of economic development. Routledge, 2017.

SHINNAR, R. S.; GIACOMIN, O.; JANSSEN, F. Entrepreneurial perceptions and intentions: The role of gender and culture. Entrepreneurship Theory and practice, v.36, n.3, p.465-493, 2012.

SMALES, Lee A. Examining the relationship between policy uncertainty and 
market uncertainty across the G7. International Review of Financial Analysis, p. 101540, 2020.

SOLHI, S.; RAHMANIAN KOSHKAKI, E. The antecedents of entrepreneurial innovative behavior in developing countries, a networked grounded theory approach (case study Iran). Journal of Entrepreneurship in Emerging Economies, v.8, n.2, p.225-262, 2016.

VERHEUL, I.; THURIK, R.; GRILO, I.; VAN DER ZWAN, P. Explaining preferences and actual involvement in selfemployment: Gender and the entrepreneurial personality. Journal of Economic Psychology, v.33, n.2, p.325341, 2012.

WAHEEDUZZAMAN, A. N. M. Competitiveness and convergence in $\mathrm{G} 7$

and emerging markets. Competitiveness Review: An International Business Journal, v.21, n.2, p.110-128, 2011.

WINGFIELD, A. H.; TAYLOR, T. Race, gender, and class in entrepreneurship: intersectional counterframes and black business owners. Ethnic and Racial Studies, v.39, n.9, p.1676-1696, 2016.

WINGFIELD, A. H.; TAYLOR, T. Race, gender, and class in entrepreneurship: intersectional counterframes and black business owners. Ethnic and Racial Studies, v.39, n.9, p.1676-1696, 2016.

PIPEROPOULOS, P. Ethnic female business owners: more female or more ethnic entrepreneurs. Journal of small business and enterprise development, v.19, n.2, p.192-208, 2012.

\footnotetext{
${ }^{1}$ Carla Carolinne dos Santos Silva

Doutoranda em Gestão. Faculdade de Ciências Sociais e Humanas, Universidade da Beira Interior UBI, Portugal.

${ }^{2}$ André Luiz Cavalcanti

Doutorando em gestão. Faculdade de Ciências Sociais e Humanas, Universidade da Beira Interior UBI, Portugal.

${ }^{3}$ Ricardo Gouveia Rodrigues

Doutor em Gestão pela Universidade da Beira Interior. Professor Auxiliar do Departamento de Gestão e Economia. Universidade da Beira Interior - UBI, Portugal.
} 